\title{
ТОПІЧНА ДІАГНОСТИКА СТУПЕНЯ УРАЖЕННЯ ЛИЦЬОВОГО НЕРВА
}

\author{
Н. Давибіда, І. Березяк \\ Тернопільський національний медичний університет \\ імені І. Я. Горбачевського МОЗ Украӥни
}

Неврит лицьового нерва - це запалення нервів, що відповідають за контроль над рухами лицьових м’язів. 98 \% випадків невриту супроводжуються явною лицьовою асиметрією, помітною в стані спокою і різко посиленою при мімічних рухах. Одужання настає протягом двох-трьох тижнів, але в деяких випадках повне відновлення міміки може тривати до року. Тому важливо розпочинати лікування якомога раніше, щоб не допустити ускладнень. Повне одужання спостерігають у 75 \% пацієнтів.

\section{TOPICAL DIAGNOSIS OF FACIAL PALSY}

\author{
N. Davybida, I. Berezyak
}

\section{Horbachevsky Ternopil National Medical University}

Facial neuritis is an inflammation of the nerves responsible for controlling facial movements. $98 \%$ of cases of neuritis are accompanied by obvious facial asymmetry, noticeable at rest and sharply amplified by facial movements. Recovery occurs within two to three weeks, but in some cases, a full restoration of facial expressions can last up to a year. Therefore, it is important to start treatment as early as possible in order to prevent complications. Full recovery is observed in $75 \%$ of patients.

Вступ. Сьогодні, як і сотні років тому, людину «переслідують» хвороби, яких не стає менше. Серед захворювань периферійної нервової системи неврит лицьового нерва за поширеністю посідає друге місце, поступаючись лише неврологічним проявам остеохондрозу хребта, і залишається однією із найактуальніших проблем сьогодення. Це пов'язано з соціальними умовами суспільного життя, які постійно змінюються, ускладнюються і висувають підвищені вимоги до застосування та впровадження нових методик ЛФК при запаленні лицьового нерва. У різних регіонах світу захворюваність на периферійний параліч лицьового нерва на 100000 населення складає 16-25 випадків. Хворіють люди різного віку, але частіше молодшого. Це захворювання призводить до тривалої тимчасової непрацездатності. До того ж косметичний дефект, який виникає при цьому захворюванні, особливо при недостатньому відновленні функції мімічної мускулатури, приносить хворим страждання і переживання. Тим часом питання лікування периферійних паралічів лицьового нерва висвітлені неповністю. У багатьох хворих воно $\epsilon$

(с) Н. Давибіда, І. Березяк, 2020 недостатньо ефективним. За даними різних авторів [10-12], одужання і значне поліпшення настає тільки у 60-75 \% хворих. У кожного 4-5 пацієнта розвивається контрактура мімічних м'язів.

Під впливом неблагоприємних дій відбувається спазм судин, що беруть участь у кровопостачанні лицьового нерва, що призводить до ішемії нерва. Тривала ішемія є причиною порушення проникності судинної стінки, збільшення транссудації, набряку нерва і стиснення його у вузькому фаллопієвому каналі, порушується венозний відтік і лімфовідтік. Тривала компресія призводить до порушення провідності по нерву, його дегенерації.

Основна частина. Продіагностувати периферійний параліч лицьового нерва не складно. Діагноз ґрунтується на типовій клінічній картині, яка характеризується парезом або паралічем мімічної мускулатури на відповідній половині обличчя. Знижуються або зникають надбрівний і кореальний рефлекси. При центральному паралічі лицьового нерва в основному страждає нижня мімічна мускулатура на стороні протилежного осередку ураження, а верхня (лобовий м'яз, круговий м'яз ока) майже повністю 
зберігає функцію, оскільки верхня клітинна група ядра лицьового нерва має двосторонній зв'язок із корою головного мозку через кірково-ядерні шляхи [5, 7, 8]. Крім того, центральний параліч лицьового нерва звичайно поєднується з геміплегією або геміпарезом на тій стороні. При центральному паралічі лицьового нерва надбрівний і кореальний рефлекси збережені, відсутні розлади смаку, слиновиділення, сльозотечі. Проте варто зазначити, що у пацієнтів із центральним паралічем лицьового нерва, що поєднується 3 геміплегією в перші дні інсульту, може спостерігатися слабкість верхньої мімічної мускулатури, особливо кругового м'яза ока.

При проведенні топічної діагностики захворювання лицьового нерва необхідно враховувати особливості анатомічної будови нерва на різних рівнях і клінічну симптоматику, яка виникає при патологічних процесах лицьового нерва на різних рівнях. Отохірурги, які займаються внутрішньоканальною хірургією лицьового нерва, для топічної діагностики в основному використовують дослідження смаку електрогустометрію і метод кількісного визначення секреції слізних залоз - тест Ширмера [2, 11, 12]. Останній оснований на порівняльному вимірюванні секреції слізних залоз на хворій і здоровій стороні. Зниження або відсутність сльозовиділення на стороні паралічу мімічних м'язів вказує на ураження нерва на рівні колінчастого вузла або вище за нього. У повсякденній практиці для встановлення локалізації ураження лицьового нерва необхідно проводити повне неврологічне обстеження, що включає дослідження смаку за допомогою піпетки і розчинів цукру, кухонної солі, лимонної кислоти. При цьому в оцінці ступеня ураження лицьового нерва і прогнозу захворювання вирішальне значення мають електрофізіологічні методи і насамперед електроміографія [1, 3]. Проте не у всіх лікувальних установах $є$ можливість проводити ці дослідження, особливо електроміографію. Крім того, за допомогою класичної електродіагностики можна виявити зміни електрозбудливості лицьового нерва тільки через 2-3 тижні від початку захворювання, а до цього часу в ряду хворих настає поліпшення, а в деяких - навіть одужання, і зміни електрозбудливості вже не визначатимуться. Тому в практичному відношенні важливо уміти оцінити ступінь ураження мімічної мускулатури як основного клінічного критерію тяжкості невропатії лицьового нерва.

У більшості робіт [4-6, 9], що присвячені периферійним ураженням лицьового нерва, вираженість парезу або плегії мімічних м'язів та ступінь відновлення їх функцій оцінюють довільно, що нерідко призводить до різної оцінки навіть одних і тих же методів лікування.

При легкому ступені хворий може закривати очі, їжа не випадає з рота, відсутня дизартрія. При другому ступені око не закривається повністю, їжа випадає з рота, спостерігають нерізку дизартрію. При третьому ступені всі симптоми дуже виражені, аж до повної плегії мімічної мускулатури.

Ми розробили метод оцінки вираженості функціональних порушень мімічних м'язів при периферійних паралічах лицьового нерва. При цьому рухливість мімічних м'язів здорової людини оцінено в $100 \%$ :

1) наморщування лоба - $10 \%$;

2) нахмурення брів - $10 \%$;

3) зажмурювання ока $-10 \%$;

4) нормально виражений корнеальний рефлекс (подразнюється рогівка ока) - $10 \%$;

5) нормальний надбрівний рефлекс - $10 \%$;

6) оскал зубів, симетричний і немає згладженої носогубної складки - 30 \%;

7) витягування губ у трубочку - $10 \%$;

8) утримування повітря в надутих щоках - $10 \%$.

При захворюванні:

1) повна відсутність морщення лоба - $0 \%$, слабо виражена рухливість брови вгору - $3 \%$, невелика асиметрія при морщенні лоба - $7 \%$;

2) за відсутності нахмурення брови - 0\%, при невеликій рухливості брови - $3 \%$, при невеликій асиметрії нахмурення брів - $7 \%$;

3) при повній відсутності закриття ока - $0 \%$, при майже повному закритті ока (щілина 1-2 мм) - $6 \%$, при закритті ока і симптомі «вій» - від 7 до $9 \%$ залежно від вираженості симптому;

4) за відсутності корнеального рефлексу - $0 \%$, при асиметрії корнеальних рефлексів - 5 \%;

5) за відсутності надбрівного рефлексу - 0 \%, при асиметрії надбрівних рефлексів - $5 \%$;

6) при повній нерухливості кута рота - $0 \%$, при невеликій рухливості кута рота при фіксований здоровій стороні - $10 \%$, при помірно вираженій рухливості кута рота хворої сторони - $20 \%$;

7) при неможливості витягнути губи в трубочку 0 \%, при асиметричному витягуванні губ - 5 \%;

8) за відсутності утримування повітря при надуванні щік - 0 \%, повітря утримується - $10 \%$.

Пропонуємо оцінювати функцію мімічних м'язів при периферійних паралічах лицьового нерва за та- 
кими ступенями тяжкості: 0-10 \% - тяжкий ступінь ураження (повний або майже повний параліч); 11-35 \% - ступінь вираженого парезу; від 36 \% і вище - ступінь помірного парезу. Ступінь відновлення функції мімічної мускулатури оцінюють таким чином: при різниці сум відсотків після лікування і до лікування 0 - без ефекту; до 15 \% - незначне поліпшення; при відновленні функції мімічних м'язів до 65 \% і різниці більше 15 \% - поліпшення; при відновленні 66-90 \% - значне поліпшення; при відновленні 91-100 \% - практичне одужання.

Висновки. Невропатія лицьового нерва може виникнути у будь-якому віці, проте найчастіше спостерігають у молодих людей. Периферійні паралічі лицьового нерва у людей старшого віку перебігають

\section{СПИСОК ЛІТЕРАТУРИ}

1. Артюшкевич С. Клиника, дигностика и лечение невропатий лицевого нерва / С. Артюшкевич // Современная стоматология. - 2015. - № 2. - С. 23-28.

2. Ахророва Ш. Б. Возрастные и гендерные клиникопатогенетические особенности острой невропатии лицевого нерва / Ш. Б. Ахророва // Международный неврологический журнал. - 2017. - № 4 (90). - С. 52-54.

3. Бісмак О. В. Фізична реабілітація у комплексному відновленні хворих на неврит лицевого нерва / О. В. Бісмак // Молодий вчений. - 2017. - № 10 (50). - С. 211-214.

4. Довганюк А. П. Физиотерапия постневритической контрактуры мимических мышц / А. П. Довганюк // Физиотерапия. Бальнеология. Реабилитация. - 2011. № 3. - С. 54-56.

5. Эльмира С. Косметологическая коррекция асимметрии лица вследствие поражения лицевого нерва / С. Эльмира // Kosmetik international. - 2016. - № 4. C. $88-90$.

6. Ліскевич І. Ефективність лікування невропатії лицевого нерва у дітей та підлітків з урахуванням оцінки стану окисно-відновних процесів / І. Ліскевич // Міжнародний неврологічний журнал. - 2014. - № 2. - С. 13-16. менш сприятливо, ніж у молоді. Тому лікування цієї категорії хворих викликає певні труднощі. За даними, отриманими під час спостереження за хворими літнього і старечого віку, найчастішою причиною захворювання лицьового нерва $є$ переохолодження (37\%). Друге місце серед етіологічних чинників захворювання посідає судинна патологія (25,2 \%), до неї належать гіпертонічна хвороба, атеросклероз. Дилема залишитися здоровим або хворіти, яка стоїть перед кожною людиною, розв'язується її поведінкою і приблизно на 1/5 залежить від усього комплексу медичних заходів. Актуальність і недостатність розв'язання цієї проблеми зумовили вибір теми нашого дослідження.

7. Неведомська $€$. О. Анатомія та фізіологія нервової системи : навч.-метод. посіб. для практичних робіт для студ. вищ. навч. закл. / Є. О. Неведомська. - К. : Київський ун-т імені Бориса Грінченка, 2017. - 70 с.

8. Неведомська $€$. О. Методика вивчення черепних нервів / Є. О. Неведомська // Біологія і хімія в рідній школі. - 2018. - № 1. - С. 2-5.

9. Новиков Ю. О. Применение остеопатии, акупунктуры и локальной инъекционной терапии при лечении паралича Белла (серия случаев) / Ю. О. Новиков // Мануальная терапия. - 2015. - № 3. - С. 67-69.

10. Пітик М. І. Невропатія лицевого нерва у дітей: деякі аспекти діагностики та лікування / М. І. Пітик // Журнал неврології ім. Б. М. Маньковського. - 2015. - № 1. С. 80-85.

11. Постзостерный синдром Рамсея-Ханта / Ф. С. Харламова, В. Ф. Учайкин, И. М. Дроздова, А. Е. Анджель // Лечащий врач. - 2016. - № 1. - С. 12-15.

112. House J. W. Facial nerve grading system / J. W. House, D. E. Brackmann // Otolaryngol. Head Neck Surg. - 1985. Vol. 93. - P. 146-147. 